\title{
Beyond Enzyme Production: Solid State Fermentation (SSF) as an Alternative Approach to Produce Antioxidant Polysaccharides
}

\author{
Ramón Verduzco-Oliva ${ }^{1}$ and Janet Alejandra Gutierrez-Uribe ${ }^{1,2, *}$ \\ 1 Tecnologico de Monterrey, Escuela de Ingenierı y Ciencias, Centro de Biotecnologia FEMSA, Monterrey, \\ Nuevo Leon 64849, Mexico; A00826570@itesm.mx \\ 2 Tecnologico de Monterrey, Campus Puebla, Vía Atlixcáyotl 5718, Reserva Territorial Atlixcáyotl, Puebla, \\ Puebla 72453, Mexico \\ * Correspondence: jagu@tec.mx; Tel.: +55-222-303-2000 (ext. 2272)
}

Received: 27 November 2019; Accepted: 30 December 2019; Published: 8 January 2020

\begin{abstract}
Solid state fermentation (SSF) is a sustainable process that uses low amounts of water and transforms plant-based agro-industrial residues into valuable products such as enzymes, biofuels, nanoparticles and other bioactive compounds. Many fungal species can be used in SSF because of their low requirements of water, $\mathrm{O}_{2}$ and light. During SSF, plant-based wastes rich in soluble and insoluble fiber are utilized by lignocellulolytic fungi that have enzymes such as lignases, celullases or hemicelullases that break fiber hard structure. During the hydrolysis of lignin, some phenolic compounds are released but fungi also synthetize bioactive compounds such as mycophenolic acid, dicerandrol C, phenylacetates, anthraquinones, benzofurans and alkenyl phenols that have health beneficial effects such as antitumoral, antimicrobial, antioxidant and antiviral activities. Another important group of compounds synthetized by fungi during SSF are polysaccharides that also have important health promoting properties. Polysaccharides have antioxidant, antiproliferative and immunomodulatory activities as well as prebiotic effects. Fungal SSF has also proved to be a process which can release high contents of phenolics and it also increases the bioactivity of these compounds.
\end{abstract}

Keywords: solid state fermentation; phenolic compounds; enzymes; polysaccharides

\section{Introduction}

The innovation implied in the idea of turning food waste into valuable chemicals, which are used daily in human activities, is commercially attractive and involves further research in areas such as biotechnology, nanotechnology, food science and food technology [1]. There is an enormous demand for food and energy to fulfill the requirements of the increasing population and since food waste is growing too, the need of effective waste management strategies and procedures is urging as rapid urbanization continues in many countries [2]. The accumulation of food waste corresponds to $1 / 3$ of the world's total food production [3]. Currently, most countries are focused on the prevention of food waste and little is done to convert food and organic wastes and residues into new value-added products. Therefore, as food waste processes are not implemented, their potential value is overlooked.

Solid residues from agricultural industries as well as vegetable waste are potential sources of important substances that could be employed in the chemical, food, pharmaceutical and cosmetic industry. Through recent studies of food supply chain, it has been found that useful products, such as enzymes, biofuels, biodegradable plastics, nanoparticles and bioactive compounds, among others, can be obtained [2]. Among the valuable compounds that can be obtained from organic waste, polyphenols are the most abundant, as they are found in vegetables, cereals, beverages and fruits. These substances are the ones that give color and other important organoleptic features to food, in addition to many 
different beneficial effects on health to prevent or treat chronic diseases [4]. Among the several technologies used to obtain valuable compounds from organic waste, solid state fermentation (SSF) is perhaps the most promising one because of its economic and sustainable characteristics: product yielding, high efficiency and productivity, low consumption of energy and water and minimum concerns about solving disposal problems [1].

\section{Solid State Fermentation (SSF)}

Solid-state fermentation (SSF) is a fermentation process where microorganisms are able to grow in a low water environment [5]. This process is performed using microorganisms growing on moist and solid substrates that have been used for thousands of years to produce foods such as bread and cheese.

The most important aspect to consider while developing the SSF process is the choice of microorganisms and substrates. Fungi and mold are employed for SSF because they need less energy for substrate sterilization and are less susceptible to bacterial contamination. Filamentous fungi are particularly appropriate for SSF because this method simulates their natural habitat. This type of fungi is capable of synthesizing large quantities of enzymes and other metabolites under SSF conditions. Yeasts and some species of bacteria (e.g., Bacillus subtilis, Bacillus thuringiensis and Lactobacillus sp.) are considered as the second-best choice because of their ability to flourish in environments with low water activity. Streptomyces sp. and other Actinomycetes can also be employed in SSF because of their resistance to extreme conditions and capacity to colonize solid residues abundantly [6].

The most common substrate utilized in SSF are plant cultivation and forestry remains because they are underutilized and plentiful. All these wastes are comprised by cellulose, hemicellulose, starch, pectin, lignin and other fibers. Sugarcane bagasse, cassava bagasse, corn cobs, wheat bran and other cereal brans, fruit peels and pulps, coffee pulp and husks, straws and husks from distinct sources are the most frequent agro-residues used for SSF as substrates [6,7].

Most agro-industrial residues (such as residues from fruits, corn, paddy and wheat) can be changed through the use of SSF to enrich their antioxidant properties for different uses, such as animal feed [6]. Ligninolytic exoenzymes, which are produced during SSF, break the chemical links of lignin by depolymerizing the complete structure toward simpler ones. SSF can be used to obtain bioactive compounds since enzymes produced by microorganisms (such as esterases, amylase, cellulases and xylanases) release bound phenolic compounds [7]. Among the positive aspects of SSF are: no need of organic solvents to extract the released phenolic compounds; greater quality and activity of extracts; operating and capital costs are lower, etc. In the same way, SSF yields superior enzymatic productivity for numerous enzymes, it has less susceptibility to substrate hampering, and therefore, it produces a greater final concentration of desired metabolites [6]. SSF has a lot of potential to boost the extraction yield of bioactive substances that may be recovered by emerging technologies, such as ultrasound, pulsed electric fields or microwave, which have been already tested in products such as potato peels [8].

Although SSF is not a novel technology, recently, it has become a very relevant process for the production of pharmaceutical, biochemical and food products, as well as for bioenergy generation. The products obtained enable greater enzymatic productivity for numerous enzymes because they are less prone to substrate inhibition [1]. Other applications of SSF include: pigments, aroma and/or phenolic compound production, composting, biobleaching, etc. [6]. Remnants of SSF (which have a different level of biodegradability) can be used for composting, anaerobic digestion or to produce biogas [1].

\section{Phenolic Compounds in Fungi}

Phenolic substances are secondary metabolites generated mostly by plants. The biosynthesis of phenolic acids begins with phenylalanine, which is the first substrate during the phenylpropanoid route [9]. Phenolics can enter the organs through the transporter protein penetrating the compartment membrane [10]. Phenolic acids content is largely influenced by factors such as agronomic practices and environmental conditions, as well as different abiotic and biotic stimuli. Genetics influence phenolic 
acids content too because of the environmental interactions that cause a sizeable discrepancy among species and cultivars of the same species [9].

Intracellular organs (such as the endoplasmic reticulum) synthesize phenolics and later these compounds are liberated and moved into the matrix of the cell or the vacuole through a small lipid bilayer system (vesicle transfer system). This system can hold phenolics and it also makes their migration easier into the matrix of the cell wall. It has been observed that the cytoplasmic and Golgi vesicles that contain phenolics move to the plasma membrane and secrete phenolics to the cell wall matrix. Additionally, the phenolic compounds can reach the cell wall matrix as they are moved to the plasma membrane via ATP-binding cassette (ABC) transporters [10]. The phenolic compounds that were transferred are found now linked to bigger molecules (for examle, cellulose, pectin and proteins) by covalent links (such as carbon-carbon, ether and ester) [11].

Phenolic compounds are found inside the matrix of plants in three ways: free, soluble-bound (conjugated) or in insoluble-found form. Conjugated phenolics are found esterified to soluble compounds like some low molecular weight carbohydrates, proteins or lipids, while insoluble are esterified or etherified to more complex cell wall components [12]. Bound or insolvable phenolics are also called non-extractable phenolics and stay in the matrix of the biowaste after the removal process of solvable phenolics using a water-alcohol solution [13]. Phenolic non-soluble compounds are found in cell wall matrix of the vegetable cells. They can only be liberated from the matrix by a process of hydrolysis (such as acid, alkaline or enzyme hydrolysis) [10].

Since phenolic compounds have a protecting function in plants, they also should be deemed vital for the survival of endophytic fungus or at least for their mutually beneficial relationships. However, it is not clear yet if phenolic compounds have the same importance for plants than for their connected microorganisms [14].

\subsection{Biosynthesis of Phenolic Compounds in Fungi}

It has been reported that occasionally the phenolic compounds initially biosynthesized by vegetables may be found in endophytes fungi colonies. Among these compounds are: emodin, capsaicin, luteolin, hypericin and chlorogenic acid [14]. In fungal endophytes, flavonoids, phenolics and saponins are very important bioactive constituents which are considered as innovative and feasible antioxidant supplies. For example, natural antioxidant compounds such as phlorizin, rutin, gallic acid and 2,6-di-tert-butyl hydroquinone were identified in fungal filtrates from 53 different endophytes from the fermented bulbs of Fritillaria unibacteata var. wabuensis (FUW), and all of these compounds showed antioxidant activities [15].

In fungi, the Shikimate pathway has been correlated with the presence of phenolic compounds in these microorganisms. Tyrosol, a well-known phenolic compound, has been isolated from extracts of endophytes from the fermentation of various plants and it is thought to be a signaling substance in fungi species [14]. Bioactive properties of other phenolic compounds from fungi include antitumor, antimicrobial and antioxidant activities (Table 1). The interaction between the substrate and the fungi affects the production of bioactive metabolites [16]. For example, when Stemphylium globuliferum grew in solid white bean medium, it produced tetrahydroanthraquinones that were inactive against the L5178Y mouse lymphoma cell line, but when it was grown in a rice culture, other anthraquinones that inhibit the growth of the lymphoma cells were produced [17].

Ampelomyces sp., is an endophytic fungus which can synthetize several phenolic secondary compounds through solid and liquid fermentation. Some of the phenolic compounds produced by this microorganism are: mycofenolic acid, dicerandrol $C$, cytosporone $C$, phomopsin $A$, phomopsin B, altersolanol A, desmethyldiaportinol, etc. These two last compounds demonstrated favorable cytotoxic activity in vitro against L5178Y mouse lymphoma cell lines; other phenolics produced have antimicrobial action against S. aureus, S. epidermidis and E. faecalis employing minimum inhibitory concentration values between $12.5-25 \mu \mathrm{g} / \mathrm{mL}$. Pestalotiopsis sp. and Phoma pinodella can produce phenolics such as phomodione, usnic acid, cercosporamide, pestalol D and E and several others, some 
of which have antiproliferative action against a group of human tumoral cell lines (such as lung, prostate, ovary, colon, cervix, etc.) [14].

Table 1. Bioactivity of phenolic compounds synthetized by fungi.

\begin{tabular}{|c|c|c|}
\hline Phenolic Compounds & Reported Bioactivities & References \\
\hline Mycophenolic acid: (caproate) & $\begin{array}{l}\text { Immunosuppression for kidney } \\
\text { transplant recipients }\end{array}$ & [18] \\
\hline Dicerandrol C (xanthone) & Antimicrobial actions against $S$. aureus & {$[19,20]$} \\
\hline $\begin{array}{l}\text { Cytosporone B and C } \\
\text { (phenylacetates) }\end{array}$ & $\begin{array}{c}\text { Inhibitory action against } C \text {. albicans and } \\
\text { Fusarium oxysporum }\end{array}$ & [20] \\
\hline Phomopsin A and B (mycotoxins) & $\begin{array}{l}\text { In vitro activity against B. megaterium and } \\
E . \text { coli }\end{array}$ & [21] \\
\hline $\begin{array}{l}\text { Altersolanol A, B and } \mathrm{N} \\
\quad \text { (anthraquinone) }\end{array}$ & $\begin{array}{l}\text { Cytotoxic action in vitro against L5178Y } \\
\text { mouse lymphoma cell lines and } \\
\text { antimicrobial activity against } S \text {. aureus, S. } \\
\text { epidermidis and E. faecalis. }\end{array}$ & {$[22,23]$} \\
\hline $\begin{array}{l}\text { 4-dehydroaltersolanol A } \\
\text { (anthraquinone) }\end{array}$ & $\begin{array}{c}\text { Cytotoxicity against L5178 mouse } \\
\text { lymphoma cells. }\end{array}$ & {$[24,25]$} \\
\hline $\begin{array}{l}\text { Dihydroaltersolanol C and } \\
\text { acetylalterporriol E } \\
\text { (anthraquinones) }\end{array}$ & $\begin{array}{l}\text { Strong cytotoxicity against the murine } \\
\text { lymphoma cell line L5178Y. }\end{array}$ & [26] \\
\hline Alterporriol T & Inhibition of alpha-glucosidase & [26] \\
\hline Nigbeauvin A and B (azaphilones) & $\begin{array}{l}\text { Cytotoxic against tumor cells HL-60, } \\
\text { A-549, SMMC-7721, SW480 and MCF-7. }\end{array}$ & [27] \\
\hline $\begin{array}{c}\text { Phomaether A and C } \\
\text { anthraquinones) }\end{array}$ & $\begin{array}{l}\text { Strong inhibitory action against S. albus, } S \text {. } \\
\text { aureus, E. coli and V. parahaemolyticus. }\end{array}$ & [28] \\
\hline $\begin{array}{l}\text { Desmethyldiaportinol } \\
\quad \text { (isocoumarine) }\end{array}$ & $\begin{array}{l}\text { Antagonist activity in vitro against } \\
\text { L5178Y mouse lymphoma cell lines. }\end{array}$ & [25] \\
\hline Phomodione (benzofuran) & $\begin{array}{c}\text { Antagonist effect against } \text { S. aureus, } \\
\text { Pythium ultimum, Sclerotinia sclerotiorum } \\
\text { and Rhizoctonium solani }\end{array}$ & [25] \\
\hline Usnic acid (benzofuran) & $\begin{array}{l}\text { Activity against } S \text {. aureus, Acinetobacter } \\
\text { baumannii and Klebsiella pneumonia and } \\
\text { anti-inflammatory activity }\end{array}$ & [25] \\
\hline Cercosporamide (benzofuran) & $\begin{array}{c}\text { Mnk inhibitory activity via the blockage } \\
\text { of eIF4E phosphorylation. Anti-cancer } \\
\text { effects in hepatic and lung cancer, } \\
\text { leukemia and glioblastoma }\end{array}$ & {$[29,30]$} \\
\hline Pestalol D (alkenyl phenol) & $\begin{array}{l}\text { Inhibitory activity against Influenza A } \\
\text { virus subtype }\left(\mathrm{H}_{3} \mathrm{~N}_{2}\right) \text { and Swine Flue } \\
\qquad\left(\mathrm{H}_{1} \mathrm{~N}_{1}\right) \text { viruses. }\end{array}$ & {$[31,32]$} \\
\hline
\end{tabular}

\subsection{Phenols Release from Vegetable Cell Walls Using Fungi}

Microorganisms have limited accessibility to cellulose and hemicellulose in plant cell walls due to chemical connection with lignin. Fungi are the main microorganisms that recycle cellulose in nature; these organisms are well-fitted for the decomposition of biomass from plant waste because they produce an elevated number of enzymes of wide diversity and with several supportive functions. Lignocellulosic compounds involve three major groups of polymers: cellulose (linear polymer of b 1-4 of glucose bonds), hemicellulose (polymers non-cellulosic, which include glucans, mannans, arabinans, galactans and xylans) and lignin (complex polyphenol) [33]. 
Lignin is a network made by phenolic compounds and it is commonly found in secondary cell walls, especially in woody tissues. It provides structure and rigidity to cells and its proportion increases with maturation. It can be found embedded in cell walls between cellulose and hemicelluloses and its concentration depends upon cell type, stage of maturation and plant species. Lignin is synthesized in the secondary wall formation and it is found throughout the cell wall of plants [34]. Lignin contains about 40 oxygen-linked phenyl-propane elements and it is chemically inactive. Ferulic and coumaric acids are some of the most studied phenolic acids because of their abundance in plants. These compounds give rigidity to cell walls because they crosslink the sugar moieties and also lignin [12].

Fungi degrade first lignin through the effect of lignolytic enzymes (lignin peroxidase, manganese peroxidase and laccase) and then can access energy-rich polysaccharides for their metabolism and growth [5]. Enzymatic hydrolysis of phenolic conjugates not only release free phenolics but also produce lower molecular weight that contribute to increase the antioxidant activity [35]. In fruits and vegetables, phenolic compounds can be released from pectins and cellulose using enzymes such as beta-glucosidase [33].

\subsubsection{Fungal Enzymes for Cellulose Degradation}

Three matching enzymatic effects have been suggested to be accountable for cellulose decay: $\beta$-glucosidases (GH), endoglucanases (EG) and cellobiohydrolases (CBH). These enzymes can hydrolyze the $\beta-1,4$ covalent connections that attach the glucose units present in cellulose chains. $\beta$-glucosidases are non-processive enzymes due to their substrate: it must be liberated after each split activity to let the novel glucose unit to exit the compartment. Endo-1,4- $\beta$-D-glucanases, EC 3.2.1.1 arbitrarily slice $\beta-1,4$ bonds in cellulose amorphous regions; these enzymes generate different reducing and non-reducing sides with this activity. Endoglucanases, as well as $\beta$-glucosidases, are firmly hampered by their reaction compounds: cellobiose and glucose correspondingly. Cellobiohydrolases (such as cellulose 1,4- $\beta$-cellobiosidases and EC 3.2.191) are processive enzymes that liberate cellobiose (i.e., two units of glucose linked by a $\beta-1,4$ bond) from reducing or non-reducing edges from cellulose sections obtained from endoglucanases [36].

Different fungi have been used for the production of cellulases, including Aspergillus terreus, Trichoderma reesei, Aspergillus niger, Trichoderma asperellum, Pleurotus ostreatus and Aspergillus oryzae. Fungi such as Rhizomucor miehei and Aspergillus niger produce enzymes such as cellulases and pectinases that break the cellulosic chains to obtain bioenergy from the residues [37]. The activity of these enzymes may be affected by their absorption into the lignocellulosic matrix used as substrate. This gives an additional advantage to SSF since end products may be obtained without the need of using pure enzymes [38].

Aerobic fungi have multiple enzymes that are mostly active with cellulose: lytic polysaccharide monooxygenases (LPMOs) can perform copper-mediated oxidative splitting of cellulose and AA9 enzymes can act on xylan and xyloglucan. Additionally, expansins (non-catalytic proteins) are thought to have a role in cellulose degradation (reduction of substrate viscosity as well as disruption of cellulose fibers were observed sometimes), but their mechanism has not been totally clarified because no hydrolytic activity was reported [36].

\subsubsection{Fungal Enzymes to Release Phenolic Compounds}

Ligninases are a large group of intricate enzymes (for example, peroxidases and laccases) that collaborate to break down the phenolic compounds from lignin. These enzymes cleave the carbon-carbon and carbon-oxygen bonds that hold in place the complex three-dimensional (3D) structure of lignin. Some sorts of ligninases are a class of copper enzymes (known as laccases), and other three kinds are peroxidases-lignin peroxidases, manganese peroxidases and flexible peroxidases. There is a robust synergy among all these types of enzymes and it is considered as one of the likely outstanding utilizations for lignin appreciation [36]. 
Lignocellulolytic fungi are very common in the fungal kingdom. Simple and primitive fungal species such as Chytridiomycetes up to more complex and advanced ones (such as Basidiomycetes) degrade cellulose very efficiently as they use it as a carbon supply. Fungi prefer to decompose lignin, cellulose and hemicellulose (e.g., white rot fungi) but also decompose polysaccharides and alter lignin (e.g., brown rot fungi); or may rot lignin and polysaccharides at the same time (e.g., soft rot fungi). This kind of fungi produce enzymes that, either independently or as a conglomerate, break and digest recalcitrant lignocellulose [36].

Table 2 shows the chemical and bioactive effects of secondary metabolites obtained through enzymatic fermentation. In general, enzymes increase the extraction yield of secondary metabolites due to their release from complex substrates. The substrates utilized to recover bioactive metabolites were mainly food and plant-based wastes which commonly have no further use. By using enzymes, synthetized from microorganisms or bought from commercial brands, most of the metabolites display good bioactive effects. Additionally, the energy employed during the process is lower than in traditional extraction methods (such as acid or heat extraction).

Table 2. Utilization of enzymes to obtain secondary metabolites from cellulosic materials.

\begin{tabular}{|c|c|c|c|c|}
\hline Food/Substrate & Enzyme & Chemical Effects & Bioactive Effects & Reference \\
\hline $\begin{array}{l}\text { Sweet potato (Ipomoea } \\
\text { batatas (L.)) }\end{array}$ & $\begin{array}{l}\text { Feruloyl esterases from } L \text {. } \\
\text { acidophilus }\end{array}$ & $\begin{array}{l}\text { The } \mathrm{pH} \text { values of sweet potato } \\
\text { fell from } 6.2 \text { to } 3.45 \text {. Higher } \\
\text { contents of free ferulic acid } \\
\text { and p-coumaric acid. }\end{array}$ & $\begin{array}{l}\text { Higher inhibitory effects on } \\
\text { pheochromocytoma-cancer-cell } \\
\text { proliferation. }\end{array}$ & [39] \\
\hline $\begin{array}{l}\text { Spent espresso grounds } \\
\text { (SEGs) }\end{array}$ & $\begin{array}{l}\text { Cellulase and } \\
\text { hemicellulase }\end{array}$ & $\begin{array}{l}\text { A maximum reducing sugar } \\
\text { yield. Flavonoids and } \\
\text { polyphenols increased by } \\
24.0 \% \text { and } 33.9 \% \text {, respectively. }\end{array}$ & $\begin{array}{c}\text { 2,2-diphenyl-1-picryl-hydrazyl- } \\
\text { hydrate (DPPH) free-radical } \\
\text { scavenging activity increased } \\
\text { by } 59.9 \%\end{array}$ & [40] \\
\hline Oats (Avena sativa L.) & $\begin{array}{l}\alpha \text {-amylase and xylanase } \\
\text { produced by Monascus } \\
\text { anka in solid state } \\
\text { fermentation. }\end{array}$ & $\begin{array}{l}\text { The phenolic content increased } \\
\text { significantly, especially the } \\
\text { ferulic acid in the insoluble } \\
\text { fraction and the vanillic acid } \\
\text { in the soluble portion. }\end{array}$ & & [41] \\
\hline Rice bran & $\begin{array}{c}\text { Carbohydrases } \\
\text { (Viscozyme, Termamyl, } \\
\text { Celluclast, AMG, Ultraflo } \\
\text { and Pentopan) }\end{array}$ & $\begin{array}{l}\text { Increased the amount of } \\
\text { extractable phenolic acids by } \\
2.5-3.0 \text { times. }\end{array}$ & $\begin{array}{l}\text { Significant increase in ferric } \\
\text { reducing effect (1.5-3.3 times). }\end{array}$ & [42] \\
\hline Steamed rice bran & $\begin{array}{l}\text { alpha-amylase, complex } \\
\text { enzymes obtained from } \\
\text { lactic acid bacteria. }\end{array}$ & $\begin{array}{l}\text { Enhanced the whole phenolics } \\
\text { and flavonoids of aqueous } \\
\text { solutions from rice bran } \\
\text { pretreated with } \alpha \text {-amylase. }\end{array}$ & $\begin{array}{l}\text { The antioxidant action of } \\
\text { aqueous solutions also } \\
\text { increased after the process. }\end{array}$ & [43] \\
\hline $\begin{array}{c}\text { Black grape (Vitis vinifera } \mathrm{x} \\
\text { (Vitis labrusca } x \text { Vitis } \\
\text { riparia)) pomace, and apple } \\
\text { (Malus domestica cv. } \\
\text { Jonagold) and yellow } \\
\text { pitahaya (Hylocereus } \\
\text { megalanthus) peel, core, } \\
\text { peduncle and seed } \\
\text { mixture. }\end{array}$ & $\begin{array}{l}\text { Cellulase and pectinase } \\
\text { cocktails from } R \text {. miehei } \\
\text { NRRL } 5282 \text { and Aspergillus } \\
\text { niger, respectively. }\end{array}$ & $\begin{array}{l}\text { Release of free phenolic } \\
\text { compounds. }\end{array}$ & $\begin{array}{l}\text { Increase the antioxidant effects } \\
\text { of the phenolics as established } \\
\text { by } \\
\text { 1,1-diphenyl-2-picrylhydrazyl } \\
\text { radical inhibition or ferric } \\
\text { reducing antioxidant action } \\
\text { analyses. }\end{array}$ & [37] \\
\hline $\begin{array}{l}\text { Watermelon (Citrullus } \\
\text { lanatus Thunb) rind } \\
\text { (WMR) }\end{array}$ & $\begin{array}{c}\text { Enzyme cocktail } \\
\text { composed of pectinase, } \\
\text { endo- } 1,3(4)-\beta \text {-glucanase, } \\
\alpha \text {-amylase, endo- } 1, \\
4-\beta \text {-xylanase and } \\
\text { bacillolysine (protease). }\end{array}$ & $\begin{array}{l}\text { Release of antioxidant } \\
\text { phenolics up to } 3 \text { folds on } \\
\text { fresh weight basis compared } \\
\text { to conventional solvent } \\
\text { extraction with substantial } \\
\text { level of all phenolics. }\end{array}$ & $\begin{array}{l}\text { WMR extracts retained most } \\
\text { of their antioxidant properties. }\end{array}$ & [44] \\
\hline $\begin{array}{c}\text { Pigmented and } \\
\text { non-pigmented rice bran }\end{array}$ & Cellulase and/or xylanase. & $\begin{array}{c}\text { Rise in the quantity of soluble } \\
\text { oryzanol. }\end{array}$ & $\begin{array}{c}\text { Rise in the free radical } \\
\text { scavenging activity and total } \\
\text { antioxidant effect. }\end{array}$ & [45] \\
\hline $\begin{array}{c}\text { Guava (Psidium guajava) } \\
\text { leaves }\end{array}$ & $\begin{array}{c}\text { Xylanase, cellulase and } \\
\beta \text {-glucosidase. }\end{array}$ & $\begin{array}{c}\text { Enhanced the soluble } \\
\text { phenolics content and } \\
\text { flavonoids quantities by } \\
103.2 \% \text { and } 81.6 \% \text {, } \\
\text { respectively. }\end{array}$ & $\begin{array}{l}\text { Higher antioxidant effect and } \\
\text { preventive action against } \\
\text { supercoiled DNA harm. }\end{array}$ & [46] \\
\hline Ulmus pumila barks (UPB) & $\begin{array}{l}\text { Cellulase, pectinase and } \\
\beta \text {-glucosidase. }\end{array}$ & $\begin{array}{l}\text { Higher extraction yield of total } \\
\text { phenolic compounds (TP). }\end{array}$ & $\begin{array}{l}\text { Higher in vitro antioxidant } \\
\text { activity was observed using } \\
\text { the Fluorescence Recovery } \\
\text { After Photobleaching (FRAP) } \\
\text { and DPPH methods. }\end{array}$ & [47] \\
\hline
\end{tabular}


Table 2. Cont.

\begin{tabular}{|c|c|c|c|c|}
\hline Food/Substrate & Enzyme & Chemical Effects & Bioactive Effects & Reference \\
\hline Black tea leftover (BTLO) & $\begin{array}{l}\text { Kemzyme, alcalase, acid } \\
\text { cellulase, Pectinex and } \\
\text { viscozyme }\end{array}$ & $\begin{array}{l}\text { The hydrolysis of BTLO with } \\
2.9 \%(w / w) \text { kemzyme at } 45^{\circ} \mathrm{C} \\
\text { and pH } 5.4 \text { for } 98 \text { bettered the } \\
\text { release of non-extractable } \\
\text { polyphenols (NEPPs). } \\
\text { The polyphenols extracts } \\
\text { obtained by SC-CO }+ \text { EtOH } \\
\text { were cleaner and richer in } \\
\text { polyphenols compared to } \\
\text { those obtained by CSE. }\end{array}$ & & [48] \\
\hline $\begin{array}{c}\text { Cherry (Cerasus } \\
\text { pseudocerasus G. Don) seeds }\end{array}$ & $\begin{array}{c}\text { The enzyme cocktail } \\
\text { included cellulase, } \\
\text { hemicellulase, and } \\
\text { pectinase. }\end{array}$ & $\begin{array}{l}\text { More bioactive components } \\
\text { (like a-tocopherol, b-carotene, } \\
\text { phospholipids and } \\
\text { phytosterols) were obtained. }\end{array}$ & & [49] \\
\hline $\begin{array}{l}\text { Pomegranate (Punica } \\
\text { granatum) peel extracts }\end{array}$ & Pectinase and cellulase. & $\begin{array}{l}\text { Enzymatic extraction did not } \\
\text { increase the extraction returns. }\end{array}$ & $\begin{array}{c}\text { Selective antimicrobial activity } \\
\text { against } S \text {. aureus, } \\
\text { Methycillin-resistant } \\
\text { Staphylococcus aureus and } \\
\text { Listeria monocytogenes. }\end{array}$ & [50] \\
\hline $\begin{array}{c}\text { Seeds of Cuscuta chinensis } \\
\text { Lam. }\end{array}$ & Cellulase and proteases. & $\begin{array}{l}\text { The combination of enzymes } \\
\text { supplied greater flavonoid } \\
\text { yields than separate enzyme } \\
\text { treatment. }\end{array}$ & $\begin{array}{l}\text { The antioxidant effects of the } \\
\text { flavonoids were directly } \\
\text { related with their quantities as } \\
\text { measured by the scavenging } \\
\text { activity of (DPPH) free radical. }\end{array}$ & [51] \\
\hline $\begin{array}{l}\text { Sargassum muticum: whole } \\
\text { algae }(\mathrm{Sm}) \text { and residual } \\
\text { algae from alginate } \\
\text { production }(\mathrm{AESm}) .\end{array}$ & $\begin{array}{l}\text { Alcalase, alcalase + } \\
\text { Protamex, amylase, } \\
\text { Protamex, celluclast, } \\
\text { Rapidase Press, Rapidase } \\
\text { TF, Rapidase UF L and } \\
\text { Viscozyme L. }\end{array}$ & Higher yield. & $\begin{array}{l}\text { One gram of extract was } \\
\text { corresponding to } 30 \mathrm{mg} \text { of } \\
\text { ascorbic acid and } 200 \mathrm{mg} \\
\text { Trolox. The treatments did not } \\
\text { influence the antagonist effect } \\
\text { of Sarsgassum muticum } \\
\text { aqueous isolates on melanoma } \\
\text { and liposarcoma cells. }\end{array}$ & [52] \\
\hline $\begin{array}{l}\text { Crude and waste seeds of } \\
\text { guarana (Paullinia cupana) }\end{array}$ & $\begin{array}{l}\text { Aqueous enzymatic } \\
\text { maceration (AEM) using } \\
\text { cellulase and pectinase. }\end{array}$ & $\begin{array}{l}\text { AEM enhanced the overall } \\
\text { produce in the extract but did } \\
\text { not efficiently extracted } \\
\text { bioactive molecules from } \\
\text { guarana seeds. }\end{array}$ & & [53] \\
\hline $\begin{array}{l}\text { Longan (Dimocargpus } \\
\text { longan Lour.) pulp }\end{array}$ & $\begin{array}{c}\text { Superfine } \\
\text { grinding-assisted } \\
\text { enzymatic treatments } \\
\text { (LP-SE) using cellulase. }\end{array}$ & $\begin{array}{c}\text { Yield, sugar quantity, } \\
\text { solubility, arabinose and } \\
\text { mannose proportion increased } \\
\text { but the apparent viscosity, } \\
\text { particle size and glucose } \\
\text { percentage decreased. }\end{array}$ & $\begin{array}{l}\text { Strong stimulation on the } \\
\text { abundance of Lactobacillus } \\
\text { plantarum, L. bulgaricus, L. } \\
\text { fermentum and Leuconostoc } \\
\text { mesenteroides. }\end{array}$ & [54] \\
\hline $\begin{array}{l}\text { Soy pulp by-product } \\
\text { (okara) }\end{array}$ & Endoproteases & $\begin{array}{l}\text { Half of the initial insoluble } \\
\text { proteins were turned into } \\
\text { water-solvable peptides. The } \\
\text { solubilization of isoflavones } \\
\text { caught in the unsolvable } \\
\text { protein matrix was detected } \\
\text { too. }\end{array}$ & $\begin{array}{c}\text { Higher antioxidant } \\
\text { effectiveness than the initial } \\
\text { substance. }\end{array}$ & [55] \\
\hline $\begin{array}{l}\text { Sesame (Sesamum indicum } \\
\text { L.) bran }\end{array}$ & $\begin{array}{l}\text { Viscozyme L., alcalase, } \\
\text { ultrasound and } \\
\text { ultrasound-supported } \\
\text { enzymatic extractions. }\end{array}$ & $\begin{array}{l}\text { Alcalase had higher protein } \\
\text { and total phenolic compounds } \\
\text { recovery than viscozyme L. }\end{array}$ & $\begin{array}{l}\text { The highest antioxidant } \\
\text { capacities (determined with } \\
\text { the DPPH method and the } \\
\text { 2,2'-azino-bis(3- } \\
\text { ethylbenzothiazoline-6-sulfonic } \\
\text { acid) (ABTS) method) were } \\
\text { found in the } \\
\text { ultrasound-assisted enzymatic } \\
\text { extraction. }\end{array}$ & [56] \\
\hline $\begin{array}{l}\text { Grape pomace and wheat } \\
\text { bran }\end{array}$ & $\begin{array}{l}\text { Two enzymatic cocktails } \\
\text { obtained from the solid } \\
\text { fermentation of grape } \\
\text { pomace and wheat bran } \\
\text { and only wheat bran by } \\
\text { the altered strain } \\
\text { Aspergillus niger 3T55B8 } \\
\text { were used. }\end{array}$ & $\begin{array}{l}\text { Total phenolic quantity } \\
\text { augmented with the rise of } \\
\text { time of enzyme production in } \\
\text { all mediums. The activities of } \\
\text { polygalacturonase and tannase } \\
\text { showed a linear correlation } \\
\text { with phenolic substances and } \\
\text { proanthocyanidins, } \\
\text { correspondingly. }\end{array}$ & Higher antioxidant potential. & [57] \\
\hline
\end{tabular}


Table 2. Cont.

\begin{tabular}{|c|c|c|c|c|}
\hline Food/Substrate & Enzyme & Chemical Effects & Bioactive Effects & Reference \\
\hline $\begin{array}{l}\text { Leaves of Viscum coloratum } \\
\quad(\mathrm{Kom}) \text { Nakai (VCP) }\end{array}$ & Cellulase. & & $\begin{array}{l}\text { The VCP extract hampered the } \\
\text { replication of HBV-DNA and } \\
\text { the emission of HBV antigens } \\
\text { and showed a better } \\
\text { antioxidant capacity. }\end{array}$ & [58] \\
\hline $\begin{array}{l}\text { Watermelon (Citrullus } \\
\text { lanatus) }\end{array}$ & $\begin{array}{l}\text { A papain digestion process } \\
\text { was employed. }\end{array}$ & & $\begin{array}{c}\text { PWR showed antagonic ability } \\
\text { to human laryngeal carcinoma } \\
\text { Hep-2 cell in a dose and time } \\
\text { depending way. }\end{array}$ & [59] \\
\hline Alfalfa (Medicago sativa L.) & $\begin{array}{l}\text { The enzyme complex used } \\
\text { consisted of cellulose, } \\
\text { papain and pectinase. }\end{array}$ & $\begin{array}{l}\text { Different proportions of } \\
\text { monosaccharides (glucuronic } \\
\text { acid, glucose, rhamnose, } \\
\text { galactose and xylose). }\end{array}$ & $\begin{array}{l}\text { Ultrasonic enzyme-aided } \\
\text { extraction had the greatest } \\
\text { extraction yield, the greatest } \\
\text { uronic acid quantity and the } \\
\text { best antioxidant effects. }\end{array}$ & [60] \\
\hline $\begin{array}{l}\text { Japanese grape (Hovenia } \\
\text { dulcis) }\end{array}$ & $\begin{array}{c}\text { Cellulase generated by } \\
\text { Bacillus amyloliquefaciens } \\
\text { DL-3. }\end{array}$ & $\begin{array}{l}\text { The enzymatic process } \\
\text { augmented the release of } \\
\text { sugars and diminished the } \\
\text { removal temperature and time } \\
\text { use for extraction. }\end{array}$ & & [61] \\
\hline $\begin{array}{c}\text { Grape (Vitis vinifera I.) } \\
\text { pomace of Syrah Cabernet } \\
\text { Sauvignon, Malbec } \\
\text { Pinot-Noir and Marselan } \\
\text { varieties. }\end{array}$ & $\begin{array}{l}\text { Pectinase and cellulase } \\
\text { from Aspergillus niger; and } \\
\text { tannase from A. oryzae. }\end{array}$ & $\begin{array}{l}\text { The enzymatic treatment } \\
\text { augmented by } 66 \% \text { the } \\
\text { extraction of phenolics. } \\
\text { Tannase released gallic acid } \\
\text { and cellulase } p \text {-coumaric acid } \\
\text { and malvidin-3-O-glucoside. }\end{array}$ & $\begin{array}{l}\text { The enzymatic treatment } \\
\text { increased the antioxidant } \\
\text { capacity by up to } 80 \% \text {. }\end{array}$ & [62] \\
\hline
\end{tabular}

Direct treatments with enzymes (carbohydrate-cleaving enzymes mostly) are also used in preparations to release the phenolic aglycones [37]. Fungi species such as Rhyzopus oryzae, Rhyzopus oligosporus and Aspergillus oryzaei are used for solid state fermentation in several cereals [7]. These authors concluded that, although antioxidant effects of cereals can be enhanced through solid-state fermentation, these properties vary among fungi species and grains. It is also possible that some other metabolic pathways could be involved in solid-state fermentation besides the enzymatic release of phenolic compounds [5]. Shin et al. employed Aspergillus awamori and Aspergillus oryzae in order to ferment black rice bran (BRB) for 5 days. They found that although a moisturizing and autoclaving pre-treatment before fermentation lessened total phenolic content (TPC), fermentation boosted TPC specially protocatechuic acid and ferulic acid, which displayed the most considerable raises [63]. Wang et al. fermented guava leaves (GL) utilizing Monascus anka and Bacillus sp. and found that the fermenting process affect the composition and quantities of biochemical substances. Specifically, quercetin, kaempferol, gallic acid and quercetin-3-O- $\alpha$-L-arabinopyranoside were the pointer elements accountable for the variations in the bioactivities of GL throughout fermentation; total flavonoids and phenolics content, kaempferol and quercetin correlated with their bioactivities very well [64].

During fermentation, the glycosylation degree of phenolic compounds changes and in consequence their bioactivity. For example, Wang et al. used complex enzyme-assisted extraction (CEAE) in guava leaves (GL) to heighten the biodisponibility of insoluble-attached phenolic compounds. By using this enzymatic treatment these authors found that the soluble phenolics content, the flavonoids content, as well as the ABTS, DPPH and FRAP improved greatly by 103.2\%, 81.6\%, 104.4\%, $126.5 \%$ and 90.3\%, correspondingly. Total water-solvable phenolics isolates from GL after CEAE displayed the maximum antioxidant actions and protective effects against supercoiled DNA harm. In the same way, quercetin and kaempferol contents augmented their bioactivity by 3.5 and 2.2 fold, respectively. They also found that after the CEAE, most of the phenolic substances were in their solvable form and scarcely in their insolvable-attached form [64].

\subsection{Accumulation of Phenolic Acids in Fungi Cell Walls}

In general, fungal endophytes coexists asymptomatically with their hosts and they represent an underused set of microorganisms for the detection of novel valuable substances because they can create different metabolites and have the capacity to synthesize substances that are only generated 
and isolated from more complex plants [65]. In the same manner, the antioxidant effects of fungal endophytes from therapeutic plants has gained recognition in natural product investigation during the last decades. The antioxidant compounds synthetized by fungal endophytes probably support host plants to neutralize free radicals. Fungal endophytes have the ability to provide useful forbearance to free radicals under abiotic stress circumstances and they also can encourage development through biosynthesis of plant hormones and the attainment of nutrients [15].

Edible fungi contain bioactive glycolipids, aromatic phenols, fatty acid derivatives, polyacetylamine, poliketides, shikimic acid derivatives, sesquiterpenoids and many others [66]. Yeasts are enclosed by an inflexible cell wall, which is about $25-30 \%$ of the cell's dry weight. Polysaccharides extracted from yeasts' cell walls have showed important properties for human health beyond their function as structural organ, such as antioxidant, antiproliferative and immunomodulatory. For example, Galinari et al. studied the pharmacological properties of the $\alpha$-mannan-rich fraction of the cell wall of the yeast Kluyveromyces marxianus CCT7735 in order to evaluate its chelating and cytotoxic activities [67].

Phenolic acids are commonly found in their free form in fungi and there is evidence that they are absorbed by the human body in their free form as well. After being ingested, they are absorbed and conjugated (glucuronated mainly) in the same pathways as flavonoids and other polyphenols [16]. In contrast to phenolic acids, flavonoids are not found in fungi fruiting bodies, since edible fungi lack the key enzymes implicated in the flavonoids metabolic route and they are not able to store the flavonoids present in growth substrates [68,69].

\section{Bioavailability and Digestibility of Bound Phenolics}

Bioavailability of phenolic compounds is essential for their biological properties. Plants, grains and vegetables in general have a tendency to have elevated quantities of phenolic acids but they are mainly in biologically unavailable and in an insoluble-bound structure. In maize, for example, the majority of the phenolic acids are insoluble-linked hydroxycinnamic acids. Through the effect of different processing technologies (such as nixtamalization, extrusion/cooking and steaming/autoclaving) many of these insoluble-bound phenolics are converted to their bioavailable, soluble state [70].

Phenolic acids are metabolized and move through the organism in their sulphated, methylated and glucuronated forms that affect their bioactivity. This process is very important because it involves not only detoxification, but also because it increases the hydrophilicity of phenolics to facilitate their elimination via urine and billis. For example, in plasma from patients who had consumed a specific amount of coffee, numerous methylated, sulphated and glucuronated metabolites of phenolic acids were found [16]. Additionally, polyphenols found in plasma are conjugated derivatives attached to albumin. In general, polyphenols are excreted through the biliary route toward the duodenum where they are subjected to the action of bacterial enzymes, specially b-glucuronidase. After the action of enzymes on them, polyphenols can be absorbed again, which can cause a lengthier occurrence of these compounds inside the organism [16].

Humans lack $\beta$-glucosidases and esterases to degrade dietary fiber that is water-insoluble and highly cross-linked. To improve bioavailability, it is convenient to transform insolvable cereal phenolics into solvable type; this process increases the health benefits obtained from cereal phenolics consequently [7]. Free phenolic acids are swiftly immersed by the small intestine and subsequently conjugated [16]. Conjugated phenolics have more potent antioxidant activity than free phenolic compounds [41].

\section{Release of Soluble Conjugated Phenolics during Fermentation and Role of Microbiota}

Gastro-intestinal microbiota is present all along from the mouth to the anus and it is composed by microorganisms (such as bacteria, fungi, viruses and archaea); bacteria being the majority group overwhelmingly. Microbiota is an ecosystem which is partially stable and bacteria here can resist important changes that happen in their dynamic environment [34]. These modifications in the 
configuration of microbiota in humans can be understood in terms of diet, the influence of the immune system, chemical contacts or initial impacts of original colonizers [71].

Commonly, phenolics that are found in food are found as glycosides, esters or polymers that cannot pass through enterocytes, and thus, they have to be hydrolyzed by enzymes in the colon or they also can be catabolized by microbiota before their absorption [72]. For example, it has been revealed that existence of an extremely complicated xylan-decomposing system inside the large intestinal microbiota that can identify separate types of intricate carbohydrates and can react suitably [73]. Polymerized polyphenols such as ellagitannins and proanthocyanins (commonly present in walnuts and pistachios) can be digested by microbiota present in the colon, and subsequently, providing a large range of low molecular weight phenolic metabolites (such as alkylphenols, tyrosols and phenolic acids) that seem to alter the microbial ecosystem, including its profile, which causes prebiotic effects too [74]. All these processes carried out by gastro-intestinal microbiota also conducts to the biosynthesis of short-chain fatty acids and the liberation of attached phenolics (or non-extractable-polyphenols) [75].

The chemical structures of phenolic substances have impact over the conjugation reactions and also over the quantity of metabolites generated by the microflora in the colon. An example of this is chlorogenic acid, because the bound ester has the ability to modify its biological characteristics; the only local reaction in the human body where chlorogenic metabolism is involved takes place in the colon and is performed by bacteria because there are no esterases in the human organism that can free caffeic acid from chlorogenic acid. In the same way, ferulic and other hydroxycinnamic acids attached to cell walls cannot be released by human enzymes; to liberate these compounds, microbial enzymes from the colonic microflora are needed, such as esterases and xylanases. However, when these molecules are hydrolyzed by microbial enzymes, the efficiency absorption decreases because they can decompose aglycones and simple aromatic acids are released. Because of this, the absorption efficiency of phenolic acids is notably reduced when they are in their esterified form rather than in their free structures [16].

Bioavailability of anthocyanins is commonly low but through gut fermentation, the microbiota increase the bioavailability and in consequence the antioxidant and antidiabetic properties [76]. Intestinal metabolites of blackberry anthocyanins enhance the glucose consumption and glycogen content in HepG2 cells and show important antioxidant properties [77]. Microbiota plays a key role in intestinal fermentation of polyphenols, such as anthocyanins and isoflavones, which transform them into lower-molecular weight phenolics. Protocatechuic aldehyde and 4-hydroxybenzoic acid are byproducts of intestinal fermentation of anthocyanins while into equol- or $O$-desmethylangolensin come from isoflavones [78].

\section{Conclusions}

SSF processes using lignocellulolytic fungi not only have been proved to be more sustainable than traditional fermentations, but they also yield higher amounts of valuable compounds as well as higher bioactivities of these substances. Additionally, there is a lot of potential to identify other metabolites besides those that the fungi release from the substrate with enhanced bioactivity. Fungal polysaccharides also have prebiotic effects to treat or prevent chronic diseases.

Author Contributions: R.V.-O. contributed with investigation writing and editing. J.A.G.-U. contributed with investigation, review and editing. All authors have read and agreed to the published version of the manuscript.

Funding: This research was funded by the Consejo Nacional de Ciencia y Tecnología (CONACYT) and the scholarship to R.V.-O. was provided by CONACYT and Tecnológico de Monterrey (CVU number 175211).

Conflicts of Interest: The authors declare no conflict of interest. 


\section{References}

1. Yazid, N.A.; Barrena, R.; Komilis, D.; Sánchez, A. Solid-State Fermentation as a novel paradigm for organic waste valorization: A review. Sustainability 2017, 9, 224. [CrossRef]

2. Ravindran, R.; Jaiswal, A.K. Exploitation of food industry waste for high-value products. Trends Biotechnol. 2016, 34, 58-69. [CrossRef] [PubMed]

3. Food and Agriculture Organization of the United Nations (FAO). Agribusiness and Value Chains. Available online: www.fao.org/sustainable-food-value-chains (accessed on 13 June 2019).

4. Yan, S.; Shao, H.; Zhou, Z.; Wang, Q.; Zhao, L.; Yang, X. Non-extractable polyphenols of green tea and their antioxidant, anti- $\alpha$-glucosidase capacity, and release during in vitro digestion. J. Funct. Foods 2018, 42, 129-136. [CrossRef]

5. Dey, T.B.; Chakraborty, S.; Jain, K.K.; Sharma, A.; Kuhad, R.C. Antioxidant phenolics and their microbial production by submerged and solid state fermentation process: A review. Trends Food Sci. Technol. 2016, 53, 60-74.

6. Soccol, C.R.; Scopel, E.; Alberto, L.; Letti, J.; Karp, S.G.; Woiciechowski, A.L.; Porto, L.; Vandenberghe, D.S. Recent developments and innovations in solid state fermentation. Biotechnol. Res. Innov. 2017, 1, 52-71. [CrossRef]

7. Dey, T.B.; Kuhad, R.C. Upgrading the antioxidant potential of cereals by their fungal fermentation under solid-state cultivation conditions. Lett. Appl. Microbiol. 2014, 59, 493-499.

8. Fritsch, C.; Staebler, A.; Happel, A.; Angel, M.; Cubero, M.; Aguil, I.; Abadias, M.; Gallur, M.; Cigognini, I.M.; Id, A.M.; et al. Processing, valorization and application of bio-waste derived compounds from potato, tomato, olive and cereals: A review. Sustainability 2017, 9, 1492. [CrossRef]

9. Laddomada, B.; Caretto, S.; Mita, G. Wheat bran phenolic acids: Bioavailability and stability in whole wheat-based foods. Molecules 2015, 20, 15666-15685. [CrossRef]

10. Shahidi, F.; Yeo, J. Insoluble-bound phenolics in food. Molecules 2016, 21, 1216. [CrossRef]

11. Perkins, M.; Smith, R.A.; Samuels, L. The transport of monomers during lignification in plants: Anything goes but how? Curr. Opin. Biotechnol. 2019, 56, 69-74. [CrossRef]

12. Cocero, M.J.; Cabeza, Á.; Abad, N.; Adamovic, T.; Vaquerizo, L.; Martínez, C.M.; Pazo-Cepeda, M.V. Understanding biomass fractionation in subcritical \& supercritical water. J. Supercrit. Fluids 2018, 133, 550-565.

13. Anokwuru, C.; Sigidi, M.; Boukandou, M.; Tshisikhawe, P.; Traore, A.; Potgieter, N. Antioxidant activity and spectroscopic characteristics of extractable and non-extractable phenolics from Terminalia sericea Burch. ex DC. Molecules 2018, 23, 1303. [CrossRef]

14. Lunardelli Negreiros De Carvalho, P.; De Oliveira Silva, E.; Aparecida Chagas-Paula, D.; Honorata Hortolan Luiz, J.; Ikegaki, M. Importance and implications of the production of phenolic secondary importance and implications of the production of phenolic secondary metabolites by endophytic fungi: A mini-review. Mini Rev. Med. Chem. 2016, 16, 259-271. [CrossRef]

15. Pan, F.; Su, T.; Cai, S.; Wu, W. Fungal endophyte-derived Fritillaria unibracteata var. wabuensis: Diversity, antioxidant capacities in vitro and relations to phenolic, flavonoid or saponin compounds. Sci. Rep. 2017, 7, 42008. [CrossRef]

16. Heleno, S.A.; Martins, A.; João, M.; Queiroz, R.P.; Ferreira, I.C.F.R. Bioactivity of phenolic acids: Metabolites versus parent compounds: A review. Food Chem. 2015, 173, 501-513. [CrossRef]

17. Moussa, M.; Ebrahim, W.; El-neketi, M.; Mándi, A.; Kurtán, T.; Hartmann, R.; Lin, W.; Liu, Z.; Proksch, P. Tetrahydroanthraquinone derivatives from the mangrove-derived endophytic fungus Stemphylium globuliferum. Tetrahedron Lett. 2016, 57, 4074-4078. [CrossRef]

18. Wagner, M.; Earley, A.K.; Webster, A.C.; Schmid, C.H.; Balk, E.M.; Uhlig, K. Mycophenolic acid versus azathioprine as primary immunosuppression for kidney transplant recipients. Cochrane Database Syst. Rev. 2015, 12. [CrossRef]

19. Du, G.; Wang, Z.; Hu, W.; Yan, K.; Wang, X.; Yang, H.; Yang, H.; Gao, Y.; Liu, Q.; Hu, Q. Three new 3-methyl-2-arylbenzofurans from the fermentation products of an endophytic fungus Phomopsis sp. and their anti-TMV activity. Phytochem. Lett. 2017, 21, 287-290. [CrossRef] 
20. De Felício, R.; Pavão, G.B.; De Oliveira, A.L.L.; Erbert, C.; Conti, R.; Pupo, M.T.; Furtado, N.A.J.C.; Ferreira, E.G.; Costa-Lotufo, L.V.; Young, M.C.M.; et al. Antibacterial, antifungal and cytotoxic activities exhibited by endophytic fungi from the Brazilian marine red alga Bostrychia tenella Ceramiales. Rev. Bras. Farmacogn. 2015, 25, 641-650. [CrossRef]

21. Egarnes, B.; Blanchet, M.R.; Gosselin, J. Treatment with the NR4A1 agonist cytosporone B controls influenza virus infection and improves pulmonary function in infected mice. PLoS ONE 2017, 12, e0186639. [CrossRef]

22. Eldeen, I.M.S.; Effendy, M.A.W. Antimicrobial agents from mangrove plants and their endophytes. In Microbial Pathogens and Strategies for Combating them: Science, Technology and Education; Méndez Vilas, A., Ed.; Formatex: Badajoz, Spain, 2013; pp. 872-882.

23. Tan, Q.; Fang, P.; Ni, J.; Gao, F.; Chen, Q.J. Metabolites produced by an endophytic Phomopsis sp. and their anti-TMV activity. Molecules 2017, 22, 2073. [CrossRef]

24. Mishra, P.D.; Verekar, S.A.; Deshmukh, S.K.; Joshi, K.S.; Fiebig, H.H.; Kelter, G. Altersolanol A: A selective cytotoxic anthraquinone from a Phomopsis sp. Lett. Appl. Microbiol. 2014, 60, 387-391. [CrossRef]

25. Shi, T.; Qi, J.; Shao, C.; Zhao, D.; Hou, X.; Wang, C. Bioactive diphenyl ethers and isocumarin derivatives from a gorgonian-derived fungus Phoma sp. Mar. Drugs 2017, 15, 146. [CrossRef] [PubMed]

26. Li, S.; Zhang, X.; Wang, X.; Zhao, C. Novel natural compounds from endophytic fungi with anticancer activity. Eur. J. Med. Chem. 2018, 156, 316-343. [CrossRef] [PubMed]

27. Chen, B.; Shen, Q.; Zhu, X.; Lin, Y. The anthraquinone derivatives from the Fungus Alternaria sp. XZSBG-1 from the saline lake in Bange, Tibet, China. Molecules 2014, 19, 16529-16542. [CrossRef]

28. Zhang, Z.X.; Yang, X.Q.; Zhou, Q.Y.; Wang, B.Y.; Hu, M.; Yang, Y.B.; Zhou, H.; Ding, Z.T. New azaphilones from Nigrospora oryzae co-cultured with Beauveria bassiana. Molecules 2018, 23, 1816. [CrossRef]

29. Francolini, I.; Giansanti, L.; Piozzi, A.; Altieri, B.; Mauceri, A. Glucosylated liposomes as drug delivery systems of usnic acid to address bacterial infections. Colloids Surf. B Biointerfaces 2019, 181, 632-638. [CrossRef]

30. Alavi, M.; Karimi, N. Biosynthesis of Ag and Cu NPs by secondary metabolites of usnic acid and thymol with biological macromolecules aggregation and antibacterial activities against multi drug resistant MDR bacteria. Int. J. Biol. Macromol. 2019, 128, 893-901. [CrossRef]

31. Liu, Y.; Sun, L.; Su, X.; Guo, S. Inhibition of eukaryotic initiation factor $4 \mathrm{E}$ phosphorylation by cercosporamide selectively suppresses angiogenesis, growth and survival of human hepatocellular carcinoma. BioMed Pharm. 2016, 84, 237-243. [CrossRef]

32. Sun, J.; Lin, X.; Zhou, X.; Wan, J.; Zhang, T.; Yang, B.; Yang, X. Pestalols A-E, new alkenyl phenol and benzaldehyde derivatives from endophytic fungus Pestalotiopsis sp. AcBC2 isolated from the Chinese mangrove plant Aegiceras corniculatum. J. Antibiot. 2014, 67, 451-457. [CrossRef]

33. Londoño-Hernández, L.; Ramírez-Toro, C.; Ruiz, H.A.; Ascacio-Valdés, J.A.; Aguilar-Gonzalez, M.A.; Rodríguez-Herrera, R.; Aguilar, C.N. Rhizopus oryzae-Ancient microbial resource with importance in modern food industry. Int. J. Food Microbiol. 2017, 257, 110-127. [CrossRef]

34. Williams, B.A.; Grant, L.J.; Gidley, M.J.; Mikkelsen, D. Gut fermentation of dietary fibres: Physico-chemistry of plant cell walls and implications for health. Int. J. Mol. Sci. 2017, 18, 2203. [CrossRef]

35. Ferreira-Leitão, V.S.; Cammarota, M.C.; Aguieiras, E.C.G.; Vasconcelos De Sá, L.R.; Fernandez-Lafuente, R.; Freire, D.M.G. The protagonism of biocatalysis in green chemistry and its environmental benefits. Catalysts 2017, 7, 9.

36. Gupta, V.K.; Kubicek, C.P.; Berrin, J.; Wilson, D.W.; Couturier, M.; Berlin, A.; Filho, E.X.F.; Ezeji, T. Fungal enzymes for bio-products from sustainable and waste biomass. Trends Biochem. Sci. 2016, 41, 633-645. [CrossRef]

37. Zambrano, C.; Kotogán, A.; Bencsik, O.; Papp, T.; Vágvölgyi, C.; Mondal, K.C.; Krisch, J.; Takó, M. Mobilization of phenolic antioxidants from grape, apple and pitahaya residues via solid state fungal fermentation and carbohydrase treatment. LWT Food Sci. Technol. 2018, 89, 457-465. [CrossRef]

38. Mejias, L.; Cerda, A.; Barrena, R.; Gea, T. Microbial strategies for cellulase and xylanase production through solid-state fermentation of digestate from biowaste. Sustainability 2018, 10, 2433. [CrossRef]

39. Shen, Y.; Sun, H.; Zeng, H.; Prinyawiwatukul, W.; Xu, W.; Xu, Z. Increases in phenolic, fatty acid, and phytosterol contents and anticancer activities of sweet potato after fermentation by Lactobacillus acidophilus. J. Agric. Food Chem. 2018, 66, 2735-2741. [CrossRef] 
40. Scully, D.S.; Jaiswal, A.K.; Abu-Ghannam, N. An investigation into spent coffee waste as a renewable source of bioactive compounds and industrially important sugars. Bioengineering 2016, 3, 33. [CrossRef]

41. Bei, Q.; Liu, Y.; Wang, L.; Chen, G.; Wu, Z. Improving free, conjugated, and bound phenolic fractions in fermented oats (Avena sativa L.) with Monascus anka and their antioxidant activity. J. Funct. Foods 2017, 32, 185-194. [CrossRef]

42. Kim, S.; Lim, S. Enhanced antioxidant activity of rice bran extract by carbohydrase treatment. J. Cereal Sci. 2016, 68, 116-121. [CrossRef]

43. Liu, L.; Zhang, R.; Deng, Y.; Zhang, Y.; Xiao, J.; Huang, F.; Wen, W.; Zhang, M. Fermentation and complex enzyme hydrolysis enhance total phenolics and antioxidant activity of aqueous solution from rice bran pretreated by steaming with a-amylase. Food Chem. 2017, 221, 636-643. [CrossRef] [PubMed]

44. Mushtaq, M.; Sultana, B. RSM based optimized enzyme-assisted extraction of antioxidant phenolics from underutilized watermelon (Citrullus lanatus Thunb.) rind. J. Food Sci. Technol. 2015, 52, 5048-5056. [CrossRef] [PubMed]

45. Prabhu, A.A.; Jayadeep, A. Enzymatic processing of pigmented and non pigmented rice bran on changes in oryzanol, polyphenols and antioxidant activity. J. Food Sci. Technol. 2015, 52, 6538-6546. [CrossRef] [PubMed]

46. Wang, L.; Wu, Y.; Liu, Y.; Wu, Z. Complex enzyme-assisted extraction releases antioxidative phenolic compositions from guava leaves. Molecules 2017, 22, 1648. [CrossRef]

47. Zhou, Z.; Shao, H.; Han, X.; Wang, K.; Gong, C.; Yang, X. The extraction efficiency enhancement of polyphenols from Ulmus pumila L. barks by trienzyme-assisted extraction. Ind. Crops Prod. 2017, 97, 401-408. [CrossRef]

48. Mushtaq, M.; Sultana, B.; Akram, S.; Anwar, F.; Adnan, A.; Rizvi, S.S.H. Enzyme-assisted supercritical fluid extraction: An alternative and green technology for non-extractable polyphenols. Anal. Bioanal. Chem. 2017, 409, 3645-3655. [CrossRef]

49. Hu, B.; Wang, H.; He, L.; Li, Y.; Li, C.; Zhang, Z.; Liu, Y.; Zhou, K.; Zhang, Q.; Liu, A.; et al. A method for extracting oil from cherry seed by ultrasonic-microwave assisted aqueous enzymatic process and evaluation of its quality. J. Chromatogr. A 2019, 1587, 50-60. [CrossRef]

50. Alexandre, E.M.C.; Silva, S.; Santos, S.A.O.; Silvestre, A.J.D.; Duarte, M.F.; Saraiva, J.A.; Pintado, M. Antimicrobial activity of pomegranate peel extracts performed by high pressure and enzymatic assisted extraction. Food Res. Int. 2019, 115, 167-176. [CrossRef]

51. Lam, C.; Wei, Y.; Sun, M.; Fang, H. Dienzyme-assisted salting-out extraction of flavonoids from the seeds of Cuscuta chinensis Lam. Ind. Crops Prod. 2019, 127, 232-236.

52. Casas, M.P.; Conde, E.; Domínguez, H.; Moure, A. Ecofriendly extraction of bioactive fractions from Sargassum muticum. Process Biochem. 2019, 79, 166-173. [CrossRef]

53. Santana, Á.L.; Macedo, G.A. Effects of hydroalcoholic and enzyme-assisted extraction processes on the recovery of catechins and methylxanthines from crude and waste seeds of guarana (Paullinia cupana). Food Chem. 2019, 281, 222-230. [CrossRef] [PubMed]

54. Huang, F.; Liu, H.; Zhang, R.; Dong, L.; Liu, L.; Ma, Y.; Jia, X.; Wang, G.; Zhang, M. Physicochemical properties and prebiotic activities of polysaccharides from longan pulp based on different extraction techniques. Carbohydr. Polym. 2019, 206, 344-351. [CrossRef] [PubMed]

55. Tejada, M.; Parrado, J.; García-quintanilla, A. Protease technology for obtaining a soy pulp extract enriched in bioactive compounds: Isoflavones and peptides. Helyon 2019, 5, e01958.

56. Görgüç, A.; Bircan, C.; Yılmaz, F.M. Sesame bran as an unexploited by-product: Effect of enzyme and ultrasound-assisted extraction on the recovery of protein and antioxidant compounds. Food Chem. 2019, 283, 637-645. [CrossRef] [PubMed]

57. Teles, A.S.C.; Chávez, D.W.H.; Oliveira, R.A.; Bon, E.P.S.; Terzi, S.C.; Souza, E.F.; Gottschalk, L.M.F.; Tonon, R.V. Use of grape pomace for the production of hydrolytic enzymes by solid-state fermentation and recovery of its bioactive compounds. Food Res. Int. 2019, 120, 441-448. [CrossRef] [PubMed]

58. Chai, Y.; Kan, L.; Zhao, M. Enzymatic extraction optimization, anti-HBV and antioxidant activities of polysaccharides from Viscum coloratum (Kom.) Nakai. Int. J. Biol. Macromol. 2019, 134, 588-594. [CrossRef]

59. Itaimi, M.; Ben, Y.; Ben, H.; Hammami, S.; Le, D.; Majdoub, H. Partial characterization and antitumor activity of a polysaccharide isolated from watermelon rinds. Int. J. Biol. Macromol. 2019, 136, 632-641. 
60. Shang, H.; Wu, H.; Dong, X.; Shi, X.; Wang, X.; Tian, Y. Effects of different extraction methods on the properties and activities of polysaccharides from Medicago sativa L. and extraction condition optimization using response surface methodology. Process Biochem. 2019, 82, 179-188. [CrossRef]

61. Park, J.; Park, K.; Lee, N.; Lee, J.; Lee, J. Enhanced extraction of reducing sugars from fruit of Hovenia dulcis with treatment of cellulase and sequential production of ethanol and acetic acid containing ampelopsin from extracted reducing sugars. Ind. Crops Prod. 2019, 139, 111522. [CrossRef]

62. Meini, M.; Cabezudo, I.; Boschetti, C.E.; Romanini, D. Recovery of phenolic antioxidants from Syrah grape pomace through the optimization of an enzymatic extraction process. Food Chem. 2019, 283, 257-264. [CrossRef]

63. Shin, H.; Kim, S.; Hun, J.; Lim, S. Solid-state fermentation of black rice bran with Aspergillus awamori and Aspergillus oryzae: Effects on phenolic acid composition and antioxidant activity of bran extracts. Food Chem. 2019, 272, 235-241. [CrossRef] [PubMed]

64. Wang, L.; Luo, Y.; Wu, Y.; Wu, Z. Impact of fermentation degree on phenolic compositions and bioactivities during the fermentation of guava leaves with Monascus anka and Bacillus sp. J. Funct. Foods 2018, 41, 183-190. [CrossRef]

65. Deshmukh, S.K.; Gupta, M.K.; Prakas, V.; Saxen, S. Endophytic fungi: A source of potential antifungal compounds. J. Fungi 2018, 4, 77. [CrossRef] [PubMed]

66. Singh, V.; Pandey, R.; Vyas, D. Antioxidant potentiality of Pleurotus ostreatus (MTCC142) cultivated on different agro wastes. Asian J. Plant Sci. 2015, 5, 22-27.

67. Galinari, É.; Araújo, D.; Lanzi, G.; Ribeiro, G.; Maria, F.; Passos, L.; Cuquetto, H.; Alexandre, H.; Rocha, O. Chemical structure, antiproliferative and antioxidant activities of a cell wall-d-mannan from yeast Kluyveromyces marxianus. Carbohydr. Polym. 2017, 157, 1298-1305. [CrossRef]

68. Gil-Ramírez, A.; Pavo-Caballero, C.; Baeza, E.; Baenas, N.; Garcia-Viguera, C.; Marín, F.R.; Soler-Rivas, C. Mushrooms do not contain flavonoids. J. Funct. Foods 2016, 25, 1-13. [CrossRef]

69. Lavelli, V.; Proserpio, C.; Gallotti, F.; Laureati, M.; Pagliarini, E. Circular reuse of bio-resources: The role of Pleurotus spp. in the development of functional foods. Food Funct. 2018, 9, 1353-1372. [CrossRef]

70. Butts-Wilmsmeyer, C.J.; Mumm, R.H.; Rausch, K.D.; Kandhola, G.; Yana, N.A.; Happ, M.M.; Ostezan, A.; Wasmund, M.; Bohn, M.O. Changes in phenolic acid content in maize during food product processing. J. Agric. Food Chem. 2018, 66, 3378-3385. [CrossRef]

71. Donaldson, G.P.; Lee, S.M.; Mazmanian, S.K. Gut biogeography of the bacterial microbiota. Nat. Rev. Microbiol. 2017, 14, 20-32. [CrossRef]

72. Shahidi, F.; Vamadevan, V.; Oh, W.Y.; Peng, H. Phenolic compounds in agri-food by-products, their bioavailability and health effects. J. Food Bioact. 2019, 5, 57-119. [CrossRef]

73. Rogowski, A.; Briggs, J.A.; Mortimer, J.C.; Tryfona, T.; Terrapon, N.; Morland, C.; Day, A.M.; Zheng, H.; Rogers, T.E.; Lowe, E.C.; et al. Glycan complexity dictates microbial resource allocation in the large intestine. Nat. Commun. 2015, 6, 7481. [CrossRef] [PubMed]

74. Rocchetti, G.; Reddy, S.; Giuberti, G.; Mandal, R.; Lucini, L.; Wishart, D.S. Edible nuts deliver polyphenols and their transformation products to the large intestine: An in vitro fermentation model combining targeted/untargeted metabolomics. Food Res. Int. 2018, 116, 786-794. [CrossRef] [PubMed]

75. Rocchetti, G.; Chiodelli, G.; Giuberti, G.; Masoero, F.; Trevisan, M.; Lucini, L. Evaluation of phenolic profile and antioxidant capacity in gluten-free flours. Food Chem. 2017, 228, 367-373. [CrossRef]

76. Gowd, V.; Bao, T.; Wang, L.; Huang, Y.; Chen, S.; Zheng, X.; Cui, S.; Chen, W. Antioxidant and antidiabetic activity of blackberry after gastrointestinal digestion and human gut microbiota fermentation. Food Chem. 2018, 269, 618-627. [CrossRef] [PubMed]

77. Gowd, V.; Bao, T.; Chen, W. Antioxidant potential and phenolic profile of blackberry anthocyanin extract followed by human gut microbiota fermentation. Food Res. Int. 2019, 120, 523-533. [CrossRef]

78. Rocchetti, G.; Lucini, L.; Lorenzo, J.M.; Barba, F.J. Gluten-free flours from cereals, pseudocereals and legumes: Phenolic fingerprints and in vitro antioxidant properties. Food Chem. 2019, 271, 157-164. [CrossRef]

(C) 2020 by the authors. Licensee MDPI, Basel, Switzerland. This article is an open access article distributed under the terms and conditions of the Creative Commons Attribution (CC BY) license (http://creativecommons.org/licenses/by/4.0/). 